Landabidea Urresti, X., \& Loos, E. F. (2015). Contemporary meanings and experiences of television in the digital age. International Journal of Digital Television, 6 (1), 43-60. DOI: http://dx.doi.org/10.1386/jdtv.6.1.43_1

\title{
Contemporary meanings and experiences of television in the digital age
}

\author{
Xabier Landabidea Urresti, University of Deusto
}

Eugène Loos, University of Amsterdam and Utrecht University

\begin{abstract}
Television was an everyday reality for millions of people at the beginning of the twenty-first century, and arguably remains one of the most important features of media-related leisure. It provides a fertile conceptual and empirical starting point for the exploration of the everyday leisure experiences of media audiences. In this article, contemporary meanings and experiences of television are examined on three dimensions, namely the practices of (watching) television, television and the understanding of everydayness, and the experience of television itself. The emerging meanings and experiences of TV in the digital age are contrasted with the continuities and momentum of more traditional forms of watching and understanding television. Differences were found among the four different age groups (younger adults, middle-aged adults, older adults and elderly) studied, as were important similarities among people belonging to the same age group. The notion and experience of television are being transformed in the digital age, and televisual leisure opportunities appear inserted both in a transforming media ecosystem and in the everyday life of people. The article argues that it is in the contested, negotiated and complex domains of leisure experience and generational belonging that we should continue to explore the
\end{abstract}


notion(s) of television by using new epistemological approaches. This will help us to understand not only its contemporary but also its future status.

\section{Keywords}

Television; leisure studies; generation studies; meanings; experiences; digital age

\section{Introduction $^{1}$}

Throughout its history, television has been at the centre of a host of transformations, technological, industrial, social and others (Dal Yong Jin 2007; Young 2011; Ross 2008). Yet what perhaps has changed the most is the experience of television (Csikszentmihalyi and Kubey 1981; Kubey and Csikszentmihalyi 1990; Tsekleves et al. 2011). Socio-historically, individuals of different ages have had very different contacts and experiences with diverse media - e.g. press, radio, cinema, television - over the course of their lives that have shaped distinctive leisure relationships with these and other media (Bolin and Westlund 2009; Ling and Thrane 2002; Taske and Plude 2011; Westlund and Färdigh 2012; Zickuhr 2011). Television, far from being the exception, is situated at the centre of these transformations and of different generations' distinct ways of relating to media in constant transformation.

This article aims to contribute to the understanding of the contemporary meanings and experiences derived from television in the digital age based on the accounts of everyday leisure relationships with television from individuals in four different age groups (younger adults, middle-aged adults, older adults and elderly) and their explanations of the role that TV plays in their everyday lives. 
The research framework will be introduced first, presenting the notions of leisure and generations in relation to the status of television in the digital age, and examining previous studies focusing on the differences and similarities among age-groups related to television. This initial framework is completed with the elaboration of a concept of audience based in leisure studies and audience research that can be used to recognize the complexity and plurality of televisual leisure and audiencehood in the digital age.

The methodology section briefly describes the sampling of the study, introduces the agegroups and comments on the epistemological aspects involved in examining the transformations of a television integrated in a digital media landscape and the significance of these transformations for the audiences.

The findings section is divided into three subsections corresponding to three aspects of televisual leisure: the practice of leisure, the notion of free time and the leisure experience. First, the measurable aspects of the practice of (watching) television are discussed and watching television identified as a universally accepted leisure practice with recognizable generational traits across the groups. The next section covers the position of television in audiences' articulation of free time in their contemporary, multifaceted media environments and identifies generational differences of perception. Lastly, the experience of television is examined in relation to experiences of generational belonging framing television reception in a complex and multidimensional social process.

This article concludes that the everyday relationships of participants with television are diverse and intrinsically linked to the field of leisure and that there are apparent differences among age groups in their leisure relationship with TV, but that generations mediate the televisual experience thereby problematizing the clear-cut age group categories. 


\section{Reframing leisure, audiences and generations}

The technological convergence of media platforms and the emergence of transmedia audiencehoods have eroded traditional media boundaries and called into question the nature and status of (watching) television in the digital age (Evans 2011; Jenkins 2010; Puig Borràs 2013). Nonetheless, although television is not what it used to be (Shimpach 2010), nor means what it once did, at the beginning of the twenty-first century for individuals of different age groups watching television remains a primary leisure activities.

Television, leisure and generations share a polysemic condition /today: establishing with certainty where they start and where they end is problematic, while the meanings that subjects can derive from the constitutive nuclei of facts and events are always diverse, multiple and complex (Cesar et al. 2008; Cuenca Amigo and Landabidea Urresti 2010; Irani et al. 2010).

\section{The interdisciplinary study of leisure}

The disputes and controversies arising from the study of leisure from very different perspectives reflect its changing status as a social phenomenon and the problematic definition of leisure. 'Perhaps it is best to realize that there is no answer to this question, or better, that there is no correct answer' (Neulinger 1981: 1). The question of leisure has been a frequent scientific and philosophical concern throughout history, and has ultimately matured into an explicit object of enquiry in order to keep up with the challenges arising from its increasing social and economic importance (Veblen 1899; Kelly 1996; Koshar 2002; Lee et al. 1994; Haldrup and Larsen 2006). After studying the interdisciplinary status of leisure studies and the most salient contributions from disciplines such as sociology, psychology, pedagogy, law, policy, economy and aesthetics, we argue that the media and leisure must be examined together in order to advance the 
understanding of leisure in contemporary societies. As Max Kaplan argued in the second half of the twentieth century, both objective and subjective parameters are needed in order to try to define and measure leisure (1960). In the twenty-first century, and from the humanist leisure perspective of the Institute of Leisure Studies of the University of Deusto, leisure is a social phenomenon, an integral personal experience and a basic human right (Cuenca Cabeza 2000; Landabidea Urresti 2009). As Stebbins (2005) has argued, leisure is a satisfactory practice in which one employs the resources and abilities at one's own disposal a complex, but it is also a multidimensional experience with individual and social effects (Madariaga Ortuzar 2002). There is increasing scholarly interest in leisure and how humans experience is because as Bull et al. (2003) argued, it is also a sphere of human development with specific benefits to the quality of life to be protected and promoted by law and policy-making

\section{Audience behaviour and choices across generations}

Although generational differences have not been explicitly examined under the umbrella of leisure studies, differences between generations have been explored from a variety of perspectives in the recent audience research tradition. Van der Goot and Beentjes (2008) refer to the cohort analysis by Mares and Woodard (2006) that provides insight into the development of the amount of television viewed across the life span. Van der Goot and Beentjes (2008) also discuss studies examining the relation between motives for television viewing and age: 'This has been studied in some cross-sectional studies (e.g. Ostman and Jeffers 1983; Gunter 1998; Mundorf and Brownell 1990). Ostman and Jeffers formulated hypotheses on how motives for viewing would vary with the age of viewers. In this survey $(N=140$, age $18-87)$, three motives for using television were positively related to age (to learn things; to overcome loneliness; to find 
something to talk about), whereas two motives were negatively related with age (to forget; to pass time when bored). Also, Rubin and Rubin (e.g. A. M. Rubin and R. B. Rubin 1982) conducted several surveys among adult and older samples in which they included their contextual age variables and variables on television viewing motives, programme preferences and viewing behaviours. These studies showed correlations between aspects of contextual age and aspects of television use. However, the research available so far does not present a clear picture of how motives for television viewing change across the lifespan.

A previous study from Mundorf and Brownell (1990: 685) examined television viewing and magazine reading of older adults and compared the habits of this group with media preferences of college students and concluded:

Older adults $(n=74$; mean age $=72.08)$ reported higher levels of television viewing than college students $(n=149$; mean age=19.87). Viewing preferences of both groups were more similar than expected. Although more men than women reported watching television for information, most respondents cited entertainment as the primary motive for television viewing. All but older females showed a stronger preference for male characters. Magazine readership was strongly differentiated by gender and age.

Studies conducted by Harwood (1997, 1999a, 1999b) offer us insight into age identity and viewing choices. Harwood concluded:

The content analysis demonstrates that child, younger adult, and older adult television viewers demonstrate a preference for viewing characters of their own age. The experiment demonstrates that young adults' preference for viewing young adult characters exists even when the content of the program is controlled. (1997: 203) 
More recently, Van den Broeck and Pierson (2008) conducted a cross-cultural European analysis of the initiators of digital television, pre-commercial pilot projects, the role of the government and the actual available technical systems, offerings (contents, interactive services) and prices in 23 European countries. And in their study, Urban et al. (2008) described the changing viewing practices and business models in a changing business environment and challenges for policymaking in several European countries.

\section{Audiencehood as a leisure practice}

Television audiencehood is composite and plural, not simple and singular (McQuail 1997); usual and daily, not out of the ordinary (Fiske and Hartley 1978). Studying television audiences is important because of television's influence on the temporal structuring of everyday life (Gauntlett and Hill 1999), and on the shaping of experiences and understandings of leisure (Morley 1986; Morley and Brunsdon 1999). Audience measurement and the investigation of audience choices and behaviour are essential for the statistical estimation of great numbers of television viewers and are highly useful for decision-making within the market and for policymaking. However, these approaches are problematic from the point of view of leisure studies because they are tied to exposure to the medium and stranded in the quantitative measurement of the relationships with it. At the same time, the concept of publics is also problematic in terms of the relationship between the text and its readers, as publics are understood to be present, and then also readable, in the act of reception. While traditionally thought of as unmediated, contemporary publics are simultaneously direct and indirect witnesses of events through the use of increasingly ubiquitous technologies. It is increasingly difficult to draw a clear distinction between publics and audiences (Dourish 2010; Butsch 2011; D'heer et al. 2013) and traditional conceptions of 
TV viewers prove insufficient and inadequate to understand the roles of television in contemporary manifestations of leisure. A concept of audience is needed that no longer requires an immediacy between text and reader, but takes into account the full range of leisure relations occurring in everyday experience and recognizes the diversity of meanings of televisual leisure (Hermes 2009).

Television has arguably transformed the leisure world of millions since its inception, and despite the spectacular technological developments of the media ecosystem and the availability of new media choices, watching television remains one of the leisure practices most combinable with other forms of social and media activity. A cross fertilization between leisure studies and audience research can be useful to an investigation of the contemporary status of television and the study that we will present below draws on both in order to explore the meanings of television across different generations.

\section{Investigating the experience and meaning of television across generations}

Although television remains an integral part of people's leisure time, audience studies of behaviour and preferences have not given us a thorough understanding of what it means for people and how they experience it as part of leisure in todays' digital media environment, particularly across generations. Therefore, the research questions posed in this article are aimed at understanding the contemporary place of television in the everyday leisure of different generations. These are as follows: 
- What relationships do people of four different age groups (younger adults, middle-aged adults, older adults and elderly) in Biscay establish with television in their everyday life? How many of these belong to the field of leisure?

- How are leisure time, leisure practices and leisure experiences articulated in the discourses of these age groups in relation to a television inserted in a scenario of rapid technological changes? How do they perceive the opportunities and limitations of digital convergence?

- Can similarities and differences be found between these age groups regarding their leisure relationships with television? To what extent are generations and generational belonging explanatory factors for these parallelisms and divergences?

The main objective of this study was to examine the relationships of four different age groups (younger adults, middle-aged adults, older adults and elderly) with television from a humanist leisure perspective (Cuenca Cabeza 2014) in order to analyse, interpret and provide an explanation for the differences and similarities between generations (Landabidea Urresti et al. 2013). We assume that the different contacts and experiences with media that different generations have had during the course of their life have shaped distinctive leisure relationships with these media. Television is at the heart of these transformations, and constitutes the epitome of different generations' distinct ways of relating to media in constant transformation.

Exploring the televisual leisure experiences of different age groups provides a vantage point from which to examine the transformations of the media landscape and the significance of these transformations for the audiences. The methodological ambition of this article is therefore one of understanding, not of totality (Velasco et al. 2004). In line with the ethnographic statement that experience shows that intensive study provides understanding, whereas extensive study does not 
(Herskovits 1954), this required a systematic examination of the accounts of individual participant, in addition to detailed coding and recoding processes.

Understanding the nature and complexity of the phenomenon of human experience calls for a qualitative approach. Therefore this study required an ideographic approach rather than a nomothetic approach: a non-generalizing methodology, rather than a generalizing one (Rojek 2009). As this study is directed at constructing meaning and engaging in meaningful recreation, entertainment and leisure experiences, the object of study could only be approached through the narration of these experiences, as such experiences only occur within the person in question (Pohl et al. 2000; Sellar and Boshoff 2006; Vorderer 2001). The importance, meaning and significance that audiences attach to television are solely apparent through their own expression, which will always problematize external observations (Kataria and Regner 2011).

This article, therefore, does not seek any territorial representation in the sense of generalizing the findings to the entire population of Biscay, but offers an attempt to unravel the multiplicity of meanings that television has in the leisure life of the people who participated in the study in order to advance the generation of explanatory hypotheses. It examines the variations in the accounts of the televisual experience provided by four different age groups, created to facilitate maximum variation sampling (Jensen 2013) and the selection of critical cases (Flyvbjerg 2004): younger adults (18-34 years old), middle-aged adults (35-49 years old), older adults (50-64 years old) and elderly (65+ years old). The corpus used for analysis was comprised of the accounts of 73 individuals ( 39 women and 34 men) participating in ten focus groups and six indepth interviews in the region of Biscay in the Basque Country 


\section{Findings}

Taking into consideration the fact that the methodological and epistemological approaches determine the status of the research object (Hebblethwaite and Norris 2010, 2011; Roberts 2006), three interdisciplinary aspects of leisure were studied: the practice of leisure, the leisure experience and the right to leisure. Leisure as a practice focuses on the objective aspect of leisure, on the times and spaces dedicated to its materialization and on the resources available for the activity itself (Haldrup and Larsen 2006). The experience of leisure deals with the subjective dimension of leisure as an integral, whole and complex realm of human experience strongly linked to choice and freedom (Cuenca Cabeza 2014). Leisure as a human right approaches leisure as a sphere of human development with specific benefits to the quality of life to be protected and promoted by law and policy-making (Miranda Román 2006). Combining these three mutually related concepts made it possible to incorporate objective and subjective elements into an integral approach to televisual leisure from a humanist leisure perspective (Landabidea Urresti 2014). The three aspects will be covered in turn beginning with a discussion of the findings in relation to the participants' practices as television audiences.

\section{On the practice of watching television}

Starting with the measurable aspect of watching television, we found that watching television was a universally accepted leisure practice; all participants from all four age groups acknowledged television's presence in their everyday leisure repertories (Mobily et al. 1991). Nevertheless, the data also showed notable variations in how the question of whether or not they watched television was answered.

For the younger age group, television was found to be a pre-configured and unquestioned part of the everyday reality, be it in the form of the familiar background noise at home or at the 
scheduled and regular intervals of attention (at lunch, during and after dinner). Television was regarded by this age group as a part of the everyday landscape. From the heaviest viewers to those informants who showed themselves to be barely interested, television was an unquestioned element of everyday life: something that is, and always has been, present and which merits various degrees of attention depending on the personal and group agendas. In that regard, it was the broadcast content or the what to watch which constituted the linchpin of attention (to the extent of legitimizing their watching of what they consider to be junk TV shows if they include content about their favourite reality shows):

Male 25: Well, it depends on what's on ...

Female 21: Yeah, we watch Sálvame well, if they talk about Big Brother, we also watch it.

While television is part of the background for the younger group, the Middle-aged adults (aged 35-50) tended to regard it as an option, as a leisure resource that may be scarce or requiring adult supervision where children are concerned, but that may lead to the development of a personal interest and/or familial habits. For this age group, watching habits were primarily dictated by the when to watch of television (heavily nuanced by the family life).

Male 47: ... well, starting with my work schedule, I wake up at six in the morning and then I watch less television in the evening normally, because of tiredness, no? Male 39: Since becoming a father, I rarely watch TV in front of the children. I watch it mostly when they are asleep, and maybe at some special moments, maybe...

Informants belonging to the third age group, older adults, associated the practice of watching television primarily with a personal and familial leisure experience. Watching television also appeared to be constrained by family and professional needs, but much less so than in the 
younger adults group. The how much to watch ('a lot', 'not so much', 'less than before'...) and when to watch ('after dinner', 'ironing', 'on weekends'...) was the most salient:

Male 55: Yes, yes, I watch it, yes. Not much, because you know, you arrive home after work and, normally, well yes, some pieces, and then on weekends, and well, yes, but not much no, I don't know, a normal amount.

Female 51: ... television, well, I watch it... by pieces. In the morning, for example, before reading the newspaper, because I leave early, I do like to listen to the news, the weather, especially to catch the weather and if something special has happened to listen to it.

All participants from the elderly age group readily confirmed that they watched television on an everyday basis, although with very different degrees of enthusiasm. They also linked the practice of watching to the availability of interesting content, structuring the majority of interventions about watching television around what to watch. Men from this age group tended to mention films, documentaries and sports, while the women talked more about TV serials and just zapping (with exceptions in both groups). Both sexes were widely (but not exclusively) critical about reality shows, expressing their bafflement at the younger generations' fondness for these formats:

Male 77: Television, yes, we do watch it. Me myself I am more into sports eh? Apart from the news, I don't care much for the rest of all that stuff.

Female 77: I don't watch a lot of television. The news... maybe... I like things like anthropology and such. Documentaries, those I like very much. Films not so much. If it's good maybe I watch it. But I don't like television too much. I prefer going for a walk, go somewhere and watch what's to see there, that kind of thing. Television yes, a little, of course, but I don't like it too much. 
There was a general and consistent tendency among all participants in all age groups to justify their TV habits (although less so in the elderly and younger adults age groups, and more so in the group of older adults). This may partly be due to social desirability bias, stemming from the fact that watching (too much) television is perceived as socially undesirable behaviour. This negative conceptualization of television is further explored in the following sections.

\section{Television and the understanding of everydayness}

It became clear in the course of investigating the relationships between (watching) television and the experience of free time that it is well-neigh impossible to portray the leisure of a twenty-firstcentury citizen without considering the different media texts she or he consumes and participates in on an everyday basis.

Now that self-selected content viewing has become a technical possibility, television can be seen as having transformed from a receiver of distant broadcasts into a screen and mirror of viewers' interests and priorities, adjacent and connected to other communication technologies. Screens now come in a variety of sizes and capabilities. While watching television is still a popular leisure practice; its definitional boundaries are becoming problematic.

To study what television is today to audiences requires overcoming the unidirectional conception of watching, and assimilating the different understandings, uses and definitions that have emerged. From a leisure studies perspective, it requires acknowledging that watching television is more than the reception of images and sounds in front of the screen: it is a leisure practice that accumulates multiple meanings.

According to the diverse accounts of the everyday experience with television in our study, across the sample watching television was strongly tied to the idea of relaxation and 
disconnecting from the daily grind, with the exception of the elderly group, for whom it was more strongly linked with the idea of entertainment and amusement. Participants over 65 years old, especially those interviewed in a retirement home and those living alone, tended to associate all their available free time with watching television, highlighting its capacity to 'provide company' and 'entertain':

Female 67: When I have free time [I watch television] maybe all afternoon. Well, in the afternoon maybe I switch it off, then on again, but not continuously no. But well, I tell you, for me, television is company. Maybe, well, if I am sad or... I switch on the television and it's like there's someone else at home or something...

By contrast, younger informants were far more likely to associate television with 'disconnecting' from a stressful or annoying everydayness, where self-acknowledged junk-TV formats occupy a central position. Nevertheless, watching television was also frequently considered a 'lesser' form of leisure, which they would willingly exchange, given the opportunity, for other, more attractive activities:

Male 24: ... well, otherwise you live only to study, and then it's normal to get home and use those twenty minutes you have of free time watching Sálvame, you don't care what's on, because you switch on the television and you are knackered...

Male 24b: Me yes, what I don't do is spend the free time I have in front of the television, that I don't, I mean, if I can I call somebody or go get a coffee or. I mean, that is the last resort for me, in case I'm so bored, there is no one at all and well, if I'm going out at six, well, I will watch TV until six, but ... 
Both younger (18-35) and elderly (>65) informants expressed this notion of using television to fill a perceived void; both in terms of time (those hours before having an actual plan or those afternoons where there is nothing else to do) and space (at home, in the retirement home or in the lonja - $a$ term used for the social gathering place of a group of friends -).

On the other hand, informants in both the middle-aged and older adults groups tended to associate watching television with a sense of free time, alone or as a couple, once the daily tasks and duties had been fulfilled. In that sense, television has taken on the nature of an everyday pastime (almost synonymous with the daily experience of free time) that can be perceived as true entertainment when choosing a particular TV content:

Female 40: Yes, at night. Those hours at night that we all said we have in winter and summer, that free time is to have the television turned on.

Female 41: It feels, when I'm watching TV that I am enjoying my free time.

Male 55: Well yes, when you choose something, it is different when you choose [to watch] something.

Despite the obvious differences among age groups and their inner consistency in terms of the general characteristics of televisual leisure (young adults' seemingly contradictory relationship between their critical views of television and their alleged dependency of the medium; middleaged adults' markedly positive account of their televisual leisure experiences; elders' sense of wonder and amazement...), the characteristics that an age group projects into 'other generations' were often also projected towards it by members of other age groups. While age groups can be clearly distinguished, generations tend to mix and superimpose, allowing even multiple memberships to more than one generations. 


\section{Experiencing generations and television in the digital age}

Unlike the four age groups, which were delimited for the purposes of this study, television and generations are not clear-cut, self-contained entities. The notion of generations was reported by participants belonging to different age groups to be in constant interaction and contact in everyday life. It depended on subjective affiliation and identification, as well as on differentiation from other existing, and adjacent, categories. As relative constructs in constant revision, generations provide revisable identity frameworks: each member of the audience can imagine her/himself and others in front of the television and, by doing so, give form to television's daily significance.

The accounts of everyday leisure relationships with television gathered in the study showed that the meanings and experiences of television were, at the same time, more conservative (linked to a broadcast, synchronous TV signal) and transformative (more ready to exploit the opportunities of digital convergence) than initially expected. The existing notions of television held by those in our sample appear to be inextricably linked to the functions of information, entertainment/leisure and distraction/disconnection, but in varied proportions, reflecting the differences between age groups (see also Landabidea Urresti 2014). The notions of television and of the experience of television remain inconclusive, pervious and mutable (both synchronically and diachronically).

Still, the inertia of a broadcast-centred TV set was evident in all age groups. The idea of switching on the television set and tuning in to the broadcast signal was universally taken for granted and regarded as synonymous with the notion of 'watching television' during the initial stages of the focus groups and in-depth interviews. The 'starting point' for a contemporary notion of television was found to be almost exclusively linked to a traditional, more linear notion 
of television, with the few and notable exceptions evident in the middle-aged adults group - and not, as initially expected, in the youngest group:

Male 39: Well, when you say television you mean... that square box, where the pictures come from ... the device, or well, the content, the signal that comes from the air or the cable [...] I understand television as the device [...] I don't distinguish between [...] the signal coming from a channel or from the PC that I have connected to it. I mean, it's the same for me.

On the other hand, the pervasiveness of the Internet in everyday life was well acknowledged by all participants under the age of 65 and was related directly and indirectly to the interactions with television. In the group of young adults, audio-visual content was more strongly linked to the Internet than to the traditional broadcast-based television set. Although the notion of television sets connected to the Internet was recognized and argued about, television and the Internet were mentioned as separate entities, with the Internet being viewed as an infinite archive of material on which to fall back in the event of having 'missed' or not having been able to gain access to the synchronous broadcast signal of 'television':

Female 24: Maybe films and documentaries, you can download them and instead of watching them on television or having to wait some years, you can download it and in the computer... I think that happens more now.

Male 25: Yes, sometime, maybe if there is a race or cycling or something, if it's not in the television, if we don't have it at home, yes [I watch it] via the Internet, but otherwise no, just that.

Despite this rather conservative account of televisual experience and the apparent distinction between Internet and television, older age groups tended to associate new uses and conceptions 
of television with the younger members of the family and/or society. This was especially true of the elderly age group. While younger people were often cited as being the agents for discovery and the transformation of leisure habits with regard to television, this age group tended to describe their everyday leisure relationships with it as being rather traditional.

Female 47: [...] I discovered Skype when the child went to the United States, she has a big TV in her bedroom and she connects by Skype and you can call her and so on... Yes, in the TV instead of in the computer.

Male 71: Youngsters... I think they use less television. Computers, today they have all these... machines, as they have...

Female 85: They go to the Internet now.

In an age where televisual texts can be accessed through multiple (and multiplying) devices, the very experience of television becomes constitutive of the experience of belonging (or not) to a generation The allocation of technological usage (or lack of) to specific generations (other than one's own) found all over the participants' accounts reflects that the perceived shifts in what is experienced as television was one of the defining markers of generational differentiation among the age-groups. At the same time, the experience of generational belonging mediated the televisual experience and leisure relationships with the media ecosystem in general and television in particular.

\section{Conclusion: The meaning of television in the leisure of generations}

Immersed as it is in global technological, industrial and social transformations, television is being buffeted by shifts and motions that challenge its traditional centrality.Contemporary television, whether in the sense of an electronic device, a social practice or a leisure resource, is 
at a crossroads. It is still central in terms of the amount of time and attention that are devoted to it, but its position and status in the media ecosystem are changing, and so are the ways viewers understand and experience it. Television (as with other media) can therefore be considered in terms of the circulation of meanings and pleasures, and its reception as a socially situated, complex and multidimensional process. Generations, in this sense, function as historical, social and cultural frameworks, as subjective variables that may outweigh the objective elements of age: more than common experiences, generations relate to identities based on the awareness of those common experiences of the age groups.

Television has kept its name and centrality in the media ecosystem, but its social and personal leisure functions are undergoing irrevocable, albeit still relatively marginal, changes. The transformations in the form of meanings and experiences appear strongly linked to everyday leisure practices and to the changes in the perception (and investment) of free time. In that sense, a confluence of 'old' and 'new' experiences of television (Barkhuus 2009; Scolari 2008; Scolari 2009) exists that has not - yet - been articulated in the participants' discourse, that may have even gone unnoticed in the humdrum of daily life, but that emerges in the interaction with the researcher. Participants displayed the characteristic of a transitional age, in which old(er) terms are employed to express new meanings. This suggests that the leisure practices and experiences of the media - including television - are transforming more quickly than the language to express them.

This idea is enforced by the typical evolution of the fieldwork sessions, both in the focus groups and in-depth interviews: participants from all age-groups start from a classical notion of television defined by broadcast synchronous content, living room centripetal screen and prime time-centred watching patterns and end up towards the end of the session questioning the 
contemporary status of television and the nature of televisual experience today. With these constraints of transitional vocabulary in mind we return to our research questions.

The everyday relationships of the participants with television were plural and intrinsically linked to the field of leisure.

The relations with television reported by participants in all age-groups were linked to the three analytical vertices (practice, experience and free time) and significant differences were evident regarding the leisure relationships with television among the age groups. Although noteworthy similarities were found among all groups, middle-aged adults and older adults were more alike in their accounts of television as practice, while the elderly, and especially the younger adults' age-groups, tended to be more divergent.

As part of the conceptualization and experience of spare time, television's link with individual and familial free time, its perceived importance or weight in it, the characterization of television time in everyday life and the dichotomy between work and holidays were explored. When it came to filling free time (usually by watching television), the group of younger adults and the elderly age group demonstrated a somewhat similar pattern, whereas the two adult groups manifested a more scarce and valued conception of spare time, in which the merits of television were more varied and mutable. Very different reports were collected from the age groups regarding the nature of the television experience in their everyday lives that suggest the existence of different generational changes with respect to their leisure relationships with media.

Age groups reflected differences regarding their leisure relationships with television.

Different generations have had different contacts with media during their lifetime that result in distinct developments in expertise and interests, and therefore in different ways of engaging 
with media, that may be perceived as constituent and characteristic of generations (Zickuhr 2011; Bolin and Westlund 2009; Ling and Thrane 2002). In terms of the use of time, younger participants tended to have a more negative and critical discourse (although perfectly compatible with heavy viewing habits) regarding television with more balanced and positive views emerging with older ages. Younger adults' relationship with television reflected the prevalence of boredom in the account of their experience and a seemingly contradictory relationship between their critical views of television and their alleged dependency on the medium. The middle-aged adults showed a strong association between watching television and the experiencing of one's own free or spare time, combined with a markedly positive directionality of their leisure experiences of television. Older adults related to a television referred to as a 'multipurpose box' which could be adapted to the needs and desires of the moment and place, supplying relax, rest, entertainment, information or company when it is required suggesting an utilitarian, pragmatic understanding of television as an everyday life leisure resource. Finally the elderly took television as a 'window opened to the world' and related to it with a sense of wonder and amazement that could not be found in the other age-groups.

Generations not only function as explanatory factors for parallelisms and divergences, but also mediate the televisual experience and leisure relationships with television.

Changes occurring in media also constituted explicit references for generational characterization and differentiation. The point in time at which new media appear in a person's life (early years, adulthood, retirement) were employed as biographical and generational markers, and were believed to have a lasting effect on the relationship with television. Expertise was mentioned especially in relation to younger generations and new digital technologies. 
Participants watched television with members of other generations than their own, learned from and argued with each other, as they moved away and grew closer in their leisure relationships with a television in transition. It was found that the characteristics projected by an age group into 'other generations' were often, at the same time, projected towards it by members of other age groups. Moreover, while age groups are clearly delineated, generations tended to mix and superimpose, even allowing memberships to more than one generation. Age cohorts presented significant differences in terms of leisure relationships with television, but where generational belonging was stronger, it was a better indicator of the relationship with television. Hence, generations emerged as relative constructs in constant revision, built and negotiated according to subjective criteria. Far from being isolated and airtight categories, generations were reported to be in constant interaction and contact in everyday life. In that sense generations can provide a fertile approximation to the contemporary status of television and more research is needed in order to explore connection between media experience and generational belonging.

In conclusion, television offers opportunities for leisure in the context of both in a transforming media ecosystem and in the everyday lives of people. It is there, in those contested, negotiated and complex domains that we should continue to investigate the meaning and function of television for audiences. New epistemological initiatives are necessary to face the challenges of a convergent media ecosystem. We need approaches that will not be reactive to the industrial and technological changes of the digital ecosystem, but proactive in problematizing the old(er) notions of exposure and audience and bringing forward new notions of (individual and collective) meanings and experiences of television. 


\section{References}

Barkhuus, L. (2009), 'Television on the Internet: New practices, new viewers', CHI'09 Extended Abstracts on Human Factors in Computing Systems (pp. 2479-88). ACM. http://www.chi2009.org/altchisystem/submissions/submission_barkhuus_0.pdf. Accessed 16 February 2015.

Bolin, G. and Westlund, O. (2009), 'Mobile generations: The role of mobile technology in the shaping of Swedish media generations', International Journal of Communication, 3, pp. 108-24, http://www.ijoc.org/ojs/index.php/ijoc/article/viewFile/440/291. Accessed 16 February 2015.

Bull, C., Hoose, J. and Weed, M. (2003), An Introduction to Leisure Studies, Harlow: Pearson Education.

Butsch, R. (2011), ‘Audiences and publics, media and public spheres', V. Nightingale, The Handbook of Media Audiences, Oxford: Blackwell, pp. 147-68.

Cesar, P., Chorianopoulos, K. and Jensen, J. F. (2008), 'Social television and user interaction', Computers in Entertainment, $6: 1$.

Csikszentmihalyi, M. and Kubey, R. (1981), 'Television and the rest of life : A systematic comparison of subjective experience', The Public Opinion Quarterly, 45: 3, pp. 317-28.

Cuenca Amigo, J. and Landabidea Urresti, X. (2010), ‘El ocio mediático y la transformación de la experiencia en Walter Benjamin: hacia una comprensión activa del sujeto receptor / Media leisure and the transformation of the experience in Walter Benjamin: towards an active understanding of the receiving subject', Inguruak. Revista Vasca de Sociología y Ciencia Política (special issue: Sociedad e Innovación en el Siglo XXI), pp.25-40. 
Cuenca Cabeza, M. (2000), Ocio humanista: dimensiones y manifestaciones actuales del ocio/'Humanist leisure, dimensions and current manifestations of leisure', Bilbao: Universidad de Deusto. (2014), Ocio valioso/`Valuable leisure’, Bilbao: Universidad de Deusto.

Cuenca Cabeza, M., Lazcano Quintana, I. and Landabidea Urresti, X. (2010), Sobre ocio creativo: situación actual de las Ferias de Artes Escénicas/ 'Concerning creative leisure: present situation of the performing arts fairs' (eds M. Cuenca Cabeza, I. Lazcano Quintana and X. Landabidea Urresti), Bilbao: Universidad de Deusto.

Dal Yong Jin (2007), 'Transformation of the world television system under neoliberal globalization, 1983 to 2003', Television \& New Media, 8:3, pp.179-96,

D'heer, E., Verdegem, P. and Courtois, C. (2013), 'Audiences as publics. Tweeting with the television on', Selected Papers of Internet Research, 3, pp. 2012-14, http://spir.aoir.org/index.php/spir/article/view/728. Accessed 16 February 2015.

Dourish, P. (2010), 'Audiences, publics, and digital media', 'CHI 2010 Workshop on Critical Dialogue: Interaction, Experience and Cultural Theory, Atlanta, GA: CHI2010, pp. 1-5, http://www.cl.cam.ac.uk/conference/experiencingcriticaltheory/.

Evans, E. (2011), Transmedia Television: Audiences, New Media, and Daily Life, New York: Taylor \& Francis.

Fiske, J. and Hartley, J. (1978), Reading Television, Abingdon, UK: Taylor \& Francis.

Flyvbjerg, B. (2004), 'Five misunderstandings about case-study research', in C. Seale et al. (eds), Qualitative Research Practice, London and Thousand Oaks: Sage, pp. 420-34. 
Gauntlett, D. and Hill, A. (1999), TV Living: Television, Culture and Everyday Life, London and New York: Routledge.

Gunter, B. (1998), Understanding the Older Consumer: The Grey Market, London: Routledge.

Haldrup, M. and Larsen, J. (2006), 'Material cultures of tourism', Leisure Studies, 25: 3, pp. 275-89.

Harwood, J. (1997), 'Viewing age: Lifespan identity and television viewing choices', Journal of Broadcasting \& Electronic Media, 41:2, pp. 203-13.

(1999a), 'Age identification, social identity gratifications, and television viewing', Journal of Broadcasting \& Electronic Media, 43:1, pp. 123-36.

(1999b), 'Age identity and television viewing preferences', Communication Reports, 12:2, pp. 85-90.

Hebblethwaite, S. and Norris, J. E. (2010), “You don't want to hurt his feelings ...": Family leisure as a context for intergenerational ambivalence', Journal of Leisure reserach, 42:3, pp. 489-508.

(2011), 'Expressions of generativity through family leisure: Experiences of grandparents and adult grandchildren', Family Relations, 60:1, pp. 121-33, http://doi.wiley.com/10.1111/j.1741-3729.2010.00637.x. Accessed 24 November 2014.

Hermes, J. (2009), 'Audience studies 2.0. On the theory, politics and method of qualitative audience research', Interactions: Studies in Communication and Culture, 1:1, pp. 111-27.

Herskovits, M. J. (1954), 'Some problems in ethnography', in E. F. Spencer (ed.), Method and Perspective in Anthropology, Minneapolis: University of Minnesota Press, pp. 3-24. 
Irani, L., Jeffries, R. and Knight, A. (2010), 'Rhythms and plasticity: Television temporality at home', Personal and Ubiquitous Computing, 14: 7, pp. 621-32.

Jenkins, H. (2010), 'Transmedia storytelling and entertainment: An annotated syllabus', Continuum, 24:6, pp. 943-58, http://www.tandfonline.com/doi/abs/10.1080/10304312.2010.510599. Accessed 17 September 2014 .

Jensen, K. B. (2013), 'The qualitative research process', in N.W. Jankowski and K. B. Jensen (eds), A Handbook of Media and Communication Research, New York: Routledge, pp 235253.

Kaplan, M. (1960), Leisure in America: A Social Inquiry, New York: John Wiley \& Sons.

Kataria, M. and Regner, T. (2011), 'A note on the relationship between television viewing and individual happiness', Journal of Socio-Economics, 40: 1, pp. 53-58.

Katz, E. (2009), 'The end of television?', The Annals of the American Academy of Political and Social Science, 625, pp. 6-18.

Kelly, J. R. (1996), Leisure, Boston: Allyn and Bacon.

Koshar, R. (2002), Histories of Leisure, Oxford: Berg Publishers.

Kubey, R. W. and Csikszentmihalyi, M. (1990), 'Television as escape: Subjective experience before an evening of heavy viewing', Communication Reports, 3: 2, pp. 92-100.

Landabidea Urresti, X. (2009), Hacia una aproximación cualitativa a las experiencias televisivas de distintas generaciones/Towards a qualitative approach to different generations' 
televisual experiences’, Certificate of Advanced Studies Dissertation, Bilbao: Deustuko Unibertsitatea.

(2014), 'Television as an intergenerational leisure artefact : An interdisciplinary dialogue', Participations. Journal of Audience \& Reception Studies, 11:2, pp. 132-55, http://www.participations.org/Volume 11/Issue 2/9.pdf. Accessed 16 February 2015.

Landabidea Urresti, X., Aristegui Fradua, I. and Madariaga Ortuzar, A. (2013), 'De la práctica a la experiencia: innovaciones necesarias en el estudio de las audiencias televisivas'/'From practice to experience: necessary innovations in television audience research', in C. Ortega Nuere and R. San Salvador del Valle (eds), Ocio e innovación para un compromiso social, responsable y sostenible/ Leisure and innovation for a responsible and sustainable social commitment’, Bilbao: Universidad de Deusto, pp. 93-110.

Lee, Y., Dattilo, J. and Howard, D. (1994), 'The complex and dynamic nature of the leisure experience', Journal of Leisure Research, 26:3, pp. 195-211.

Ling, R. and Thrane, K. (2002), “'I don't watch TV to like learn anything”: The leisure use of TV and the Internet', First Monday, $7: 1$.

Madariaga Ortuzar, A. (2002), 'Conclusiones'/'Conclusions', in M. García Viso and A. Madariaga Ortuzar (eds), Ocio para todos. reflexiones y experiencias/'Leisure for everybody: reflections and experiences', Bilbao: Universidad de Deusto, p. 151-58.

Mannheim, K. (2011), TLe problème des générations/ The problem of generations', Paris: Armand Colin.

Mares, M. L. and Woodard, E. (2006), 'In search of the older audience: Adult age differences in television viewing', Journal of Broadcasting and Electronic Media, 50:4, pp. 595-614. 
McQuail, D. (1997), Audience Analysis, Thousand Oaks, London and New Delhi: SAGE Publications.

Miranda Román, G. (2006), 'El tiempo libre y ocio reivindicado por los trabajadores'/'Workers claim for free time and leisure', Pasos. Revista de turismo y patrimonio cultural, 4:3, pp. 301-26.

Mobily, K. E., Lemke, J. H. and Gisin, G. J. (1991), 'The idea of leisure repertoire', Journal of Applied Gerontology, 10: 2, pp. 208-23.

Morley, D. (1986), Family Television: Cultural Power and Domestic Leisure, London and New York: Routledge.

Morley, D. and Brunsdon, C. (1999), The Nationwide Television Studies, London: Routledge.

Mundorf, N. and Brownell, W. (1990), 'Media preferences of older and younger adults', Gerontologist, 30:5, pp. 685-91.

Neulinger, J. (1981), The Psychology of Leisure, Michigan: C.C. Thomas.

Ostman, R. E. and Jeffers, D. W. (1983), 'Life stage and motives for television use', International Journal of Aging and Human Development, 17:4, pp. 315-22.

Pohl, S. L., Borrie, W. T. and Patterson, M. E. (2000), 'Women, wilderness, and everyday life: A documentation of the connection between wilderness recreation and women's everyday live', Journal of Leisure Research, 32: 4, pp. 415-34.

Puig Borràs, Núria (2013), 'Narrativas transmedia. Cuando todos los medios cuentan'/'Transmedia narratives. When all media matter.', Communication Papers, 2:3, pp. 83-85, http://ojs.udg.edu/index.php/CommunicationPapers/article/view/95/puig. Accessed 16 February 2015. 
Roberts, J. (2006), Philosophizing the Everyday: Revolutionary Praxis and the Fate of Cultural Theory, London and Ann Arbor, MI: Pluto Press.

Rojek, C. (2009), The Labour of Leisure: The Culture of Free Time, Beverly Hills, CA: Sage.

Ross, S. M. (2008), Beyond the Box, Oxford, UK: Blackwell Publishing Ltd, http://doi.wiley.com/10.1002/9781444304817. Accessed 16 February 2015.

Rubin, R. B. and Rubin, A. M. (1982), 'Contextual age and television use: Reexamining a lifeposition indicator', in M. Burgoon (ed.), Communication Yearbook 6, Beverly Hills, CA: Sage, pp. 583-604.

Scolari, C. (2008), ‘Hacia la hipertelevisión. Los primeros síntomas de una nueva configuración del dispositivo televisivo'/'Towards hypertelevision. The firs symptoms of a new configuration of the televisual dispositive', Diálogos de la Comunicación. Revista Académica de la Federación Latinoamericana de Facultades de Comunicación Social, 77, pp. 1-9, www.dialnet.unirioja.es/descarga/articulo/2694422.pdf. Accessed 16 February 2015. (2009), 'The grammar of hypertelevision: An identikit of convergence-age fiction television (or, how television simulates new interactive media)', Journal of Visual Literacy, 28: 1, pp. 28-49.

Sellar, B. and Boshoff, K. (2006), 'Subjective leisure experiences of older Australians', Australian Occupational Therapy Journal, 53: 3, pp. 211-19.

Shimpach, S. (2010), Television in Transition: The Life and Afterlife of the Narrative Action Hero, Singapore: John Wiley \& Sons. 
Stebbins, A. R. (2005), 'Choice and experiential definitions of leisure', Leisure Sciences, 27: 4, pp. 349-52.

Taske, C. and Plude, F. F. (2011), 'Experiencing social media across generations', Media Development, 58: 1, pp. 38-41.

Tsekleves, E., Whitham, R., Kondo, K. and Hill, A. (2011), 'Investigating media use and the television user experience in the home', Entertainment Computing, 2: 3, pp. 151-61.

Urban, A., Sapio, B. and Turk, T. (2008), Digital Television Revisited. Linking Users, Markets and Policies, Brussels: COST Office.

Van den Broeck, W. and Pierson, J. (2008), Digital Television in Europe, Brussels: VUBPress.

Van der Goot, M. and Beentjes, Johannes W. J. (2008), 'Media use across the life-span', in Wolfgang Donsbach (ed.), The International Encyclopedia of Communication, Oxford: Blackwell Publishing.

Veblen, T. (1899), The Theory of the Leisure Class, London: MacMillan.

Velasco, H., Maillo, H. M. V. and Rada, Á. D. de (2004), La lógica de la investigación etnográfica: un modelo de trabajo para etnógrafos de la escuela /The logic of ethnographic research: a working model for school ethnographers', Madrid: Trotta.

Vorderer, P. (2001), 'It's all entertainment - Sure. but what exactly is entertainment? Communication research, media psychology, and the explanation of entertainment experiences', Poetics, 29: 4, pp. 247-61.

Westlund, O. and Färdigh, M. A. (2012), 'Conceptualizing media generations: The print, online and individualized generations', Observatorio, 6: 4, pp. 181-213. 
Young, S. (2011), 'Television studies after TV: Understanding television in the post-broadcast era', Continuиm, 25, pp. 125-29, http://www.tandfonline.com/doi/abs/10.1080/10304312.2010.506950. Accessed 16 February 2015.

Zickuhr, K. (2011), 'Generations and their gadgets', http://pewinternet.org/Reports/2011/Generations-and-gadgets.aspx. Accessed 16 February 2015.

\section{Contributor details}

Xabier Landabidea Urresti is a researcher and lecturer at the Institute of Basque Studies at the University of Deusto, Bilbao. His research interests include the contemporary forms of accessing and experiencing culture in relation to media transformations.

Eugène Loos is a professor of Old and New Media in an Ageing Society at the University of Amsterdam (ASCoR) and an associate professor Communication, Policy and Management at Utrecht University School of Governance in the Netherlands.

Contact:

E-mail: xlandabidea@deusto.es

E-mail: e.f.loos@uva.nl 
Note

${ }^{1}$ This article is based on Xabier Landabidea Urresti's Ph.D. thesis : 'Belaunaldien Telebistarekiko Aisiazko Harremanak - Bizkaiko lau adin-talderen kasu azterketa’'‘Leisure relationships with television of generations - a case study of four age-groups in Biscay' (2014). 